\title{
Global database of surface ocean particulate organic carbon export fluxes diagnosed from the ${ }^{234} \mathrm{Th}$ technique
}

\author{
F. A. C. Le Moigne ${ }^{1}$, S. A. Henson ${ }^{1}$, R. J. Sanders ${ }^{1}$, and E. Madsen* \\ ${ }^{1}$ Ocean Biogeochemistry and Ecosystems, National Oceanography Centre, Southampton, UK \\ * formerly at: School of Applied Sciences, Cranfield University, Cranfield, UK \\ Correspondence to: F. A. C. Le Moigne (f.lemoigne@ noc.ac.uk) \\ Received: 15 March 2013 - Published in Earth Syst. Sci. Data Discuss.: 27 May 2013 \\ Revised: 23 July 2013 - Accepted: 6 August 2013 - Published: 12 August 2013
}

\begin{abstract}
The oceanic biological carbon pump is an important factor in the global carbon cycle. Organic carbon is exported from the surface ocean mainly in the form of settling particles derived from plankton production in the upper layers of the ocean. The large variability in current estimates of the global strength of the biological carbon pump emphasises that our knowledge of a major planetary carbon flux remains poorly constrained. We present a database of 723 estimates of organic carbon export from the surface ocean derived from the ${ }^{234} \mathrm{Th}$ technique. The dataset is archived on the data repository PANGEA ${ }^{\circledR}$ (www.pangea.de) under doi:10.1594/PANGAEA.809717. Data were collected from tables in papers published between 1985 and early 2013. We also present sampling dates, publication dates and sampling areas. Most of the open ocean provinces are represented by multiple measurements. However, the western Pacific, the Atlantic Arctic, South Pacific and the southern Indian Ocean are not well represented. There is a variety of integration depths ranging from surface to $300 \mathrm{~m}$. Globally the fluxes ranged from 0 to $1500 \mathrm{mg} \mathrm{C} \mathrm{m}^{-2} \mathrm{~d}^{-1}$.
\end{abstract}

\section{Introduction}

The concept of the biological carbon pump, dating from the late 1970s (Eppley and Peterson, 1979), quantifies the importance of oceanic primary production in the global carbon cycle. The biological carbon pump can be divided into three stages: the production of organic matter (and biominerals) in surface waters, the sinking of these particles into the deep ocean, and the subsequent decomposition of the settling (or settled) particles in the water column or the seabed. In this way the coupling of production and export processes allows the ocean to store $\mathrm{CO}_{2}$ away from the atmosphere and contributes to the buffering of the global climate system. Without the oceanic biological carbon pump, atmospheric $\mathrm{CO}_{2}$ concentrations would be almost twice their current levels (Sarmiento and Toggweiler, 1984). Recent studies have highlighted the challenge of quantifying the magnitude of the biological carbon pump with estimates ranging from 5 to $20 \mathrm{GtC} \mathrm{yr}^{-1}$ (Henson et al., 2011).

There are several ways by which downward export fluxes can be estimated. We can divide the techniques into two groups: (1) indirect estimates based on nutrient uptake (Sanders et al., 2005; Henson et al., 2006; Pondaven et al., 2000), oxygen utilization (Jenkins, 1982), radioisotopes (Buesseler et al., 1998; Cochran and Masque, 2003; Rutgers Van Der Loeff et al., 1997b; Le Moigne et al., 2012, 2013) or by synthesising numerous biological rate processes (Boyd and Newton, 1999), and (2) direct measurements from sediments traps (Lampitt et al., 2008).

Here we focus on the ${ }^{234} \mathrm{Th}$ technique, which has the advantage that its fundamental operation allows a downward flux rate to be determined from a single water column profile of thorium coupled to an estimate of the $\mathrm{POC} /{ }^{234} \mathrm{Th}$ ratio in sinking matter (POC is particulate organic carbon; Buesseler et al., 1992). This is highly advantageous in that it removes the complications associated with sediment trap deployments and provides an integrated estimate of export (over a timescale of weeks) rather than a snapshot of export rates (Lampitt et al., 2008).

Although several comprehensive worldwide datasets of POC flux from sediment traps have been published (e.g. 
Honjo et al., 2008), to date only one thorium derived export dataset has been published (Henson et al., 2011). As part of the Seas $F X$ project (Seasonal Variability in the Efficiency of Upper Carbon Export, http://www.seasfx.info, funded by the UK National Environment Research Council), we compiled a global database of ${ }^{234} \mathrm{Th}$-derived POC export from the surface ocean $(0-300 \mathrm{~m})$. It comprises 723 data points from 1985 to 2013 covering most oceanic provinces. The dataset is archived on the data repository PANGEA ${ }^{\circledR}$ (www.pangea.de) under doi:10.1594/PANGAEA.809717.

\section{Data}

\subsection{The crux of the ${ }^{234} \mathrm{Th}$ technique}

The radioactive short-lived thorium-234 $\left({ }^{234} \mathrm{Th}, t_{1 / 2}=24.1 \mathrm{~d}\right)$ has been used as a tracer of several transport processes and particle cycling in aquatic systems by different techniques (Van der Loeff et al., 2006). The most widespread application of the ${ }^{234} \mathrm{Th}$ approach is to estimate how much POC is exported into the deep ocean (Waples et al., 2006). ${ }^{234} \mathrm{Th}$ is the daughter isotope of naturally occurring Uranium-238 $\left({ }^{238} \mathrm{U}\right.$, $t_{1 / 2}=4.47 \times 10^{9} \mathrm{yr}$ ) that is conservative in seawater and proportional to salinity in well-oxygenated environments (Ku et al., 1977; Chen et al., 1986). Unlike ${ }^{238} \mathrm{U},{ }^{234} \mathrm{Th}$ is insoluble in seawater and is particle reactive in the water column (i.e. ${ }^{234} \mathrm{Th}$ adheres to particles as they form). As particles with ${ }^{234} \mathrm{Th}$ sink through the water column, a radioactive disequilibrium is formed between ${ }^{238} \mathrm{U}$ and ${ }^{234} \mathrm{Th}$ that can be used to quantify the rate of particle export from the surface ocean.

Export rates of ${ }^{234} \mathrm{Th}$ from the surface ocean can be calculated using a one-box model (Coale and Bruland, 1987; Buesseler et al., 1992, 1998; Cochran et al., 2000; Cochran and Masque, 2003; Savoye et al., 2006; Benitez-Nelson et al., 2001a; Verdeny et al., 2008). Assuming steady state (SS) conditions, $\frac{\partial A_{2}}{\partial t}=0$ where the total ${ }^{234} \mathrm{Th}$ activity does not change with time, and no supply of ${ }^{234} \mathrm{Th}$ from physical processes (e.g. advection), the ${ }^{234} \mathrm{Th}$ flux $\left(\mathrm{dpm} \mathrm{m}^{-2} \mathrm{~d}^{-1}\right), P$, is calculated through the water column as

$P=\gamma \sum_{z=0}^{z=h}\left(A_{2}-A_{1}\right) \cdot \mathrm{d} z$

$A_{1}$ is the total parent activity concentration $\left(\mathrm{dpm} \mathrm{m}^{-3}\right)$ for ${ }^{238} \mathrm{U} ; A_{2}$ is the total ${ }^{234} \mathrm{Th}$ activity concentration $\left(\mathrm{dpm} \mathrm{m}^{-3}\right)$; $\lambda$ is the decay constant of the daughter $\left(\mathrm{d}^{-1}\right) ; h$ is the sample depth; and $P$ is the loss of the daughter due to sinking particles $\left(\mathrm{dpm} \mathrm{m}^{-2} \mathrm{~d}^{-1}\right)$. In ${ }^{234} \mathrm{Th}$ studies generally advection effects are neglected, as shown in Morris et al. (2007), with the exception of upwelling regions or areas of strong advection (Murray et al., 1992; Buesseler et al., 1998). Using the SS model from a single profile of ${ }^{234} \mathrm{Th}$ activity needs to be justified as we assume that the initial activity does not change with time (Savoye et al., 2006). If several profiles of ${ }^{234} \mathrm{Th}$ activities are measured at the same site over a certain period of

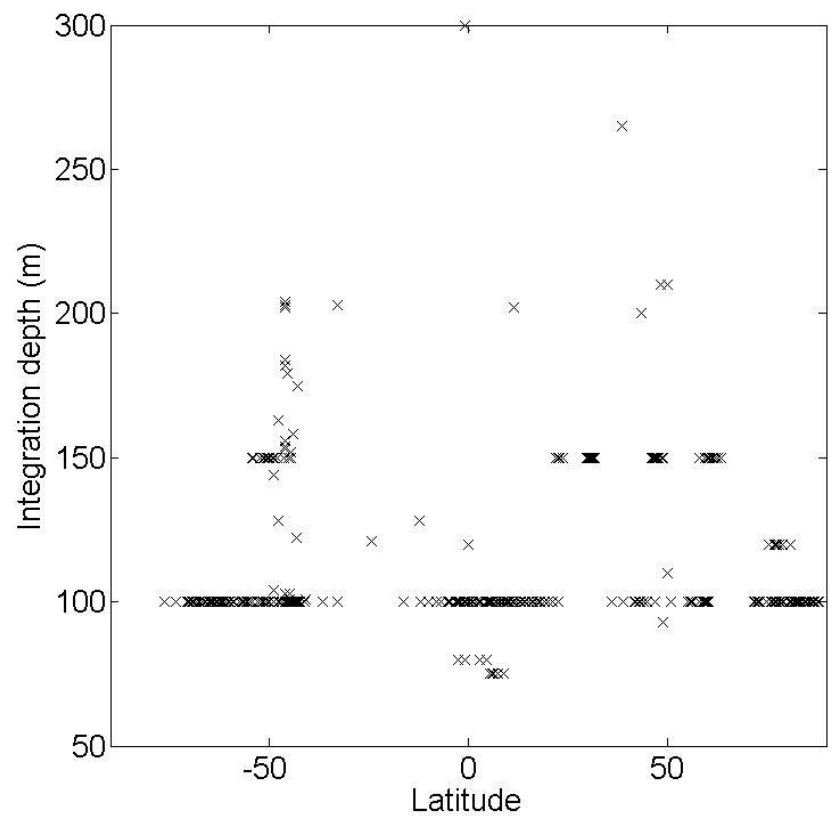

Figure 1. Integration depth of the ${ }^{234} \mathrm{Th}$ fluxes versus latitude.

time (weeks or months), a non-steady-state (NSS) model has to be applied. The NSS model may also be used during temporally variable periods with high particle flux events, such as the onset of a bloom (Buesseler et al., 1998). The NSS model factors in the term $\frac{\partial A_{2}}{\partial t}$ that is set to zero in the SS model (Eq. 2 below).

$P=\lambda \sum_{z=0}^{z=h}\left[\left(A_{2}-A_{1}\right)\right]-\frac{\partial A_{2}}{\partial t} \mathrm{~d} z$

We report ${ }^{234}$ Th fluxes from both SS and NSS models in our database. Reported ${ }^{234} \mathrm{Th}$ fluxes were integrated from depths ranging from the surface down to $300 \mathrm{~m}$ (Fig. 1 and Table 1). The vast majority of fluxes are integrated to between 100 and $150 \mathrm{~m}$. A few studies report ${ }^{234} \mathrm{Th}$ integrated over greater depths, but not more than $300 \mathrm{~m}$ depth (Table 1). In the final stage of the thorium methodology, the estimated ${ }^{234} \mathrm{Th}$ flux is converted to POC export by applying the ratio of POC to particulate ${ }^{234} \mathrm{Th}$ activity.

\subsection{Determination of POC : ${ }^{234}$ Th ratio of sinking particles}

The accuracy of the Th method relies critically on estimating the $\mathrm{POC} /{ }^{234} \mathrm{Th}$ ratio of material sinking from the upper ocean (Buesseler et al., 2006). This estimate is most frequently achieved by assuming that sinking carbon is contained within large particles, often greater than $50 \mu \mathrm{m}$ in size (or $53 \mu \mathrm{m}$, depending on the mesh supplier), whereas organic carbon within small particles is suspended in the water column, and is therefore assumed to be insufficiently large and/or dense to sink (Bishop et al., 1977; Fowler and Knauer, 1986). Size 
Table 1. Sampling year, area, number of samples $(N)$, model used (see text, Sect. 2.1), C: Th size fraction ("Part." refers to the entire particulate fraction) and reference of studies used in the database. "Traps" is indicated when $\mathrm{C}:$ Th ratio were measured in sediment traps and "Equ." refers to equilibrium depth.

\begin{tabular}{|c|c|c|c|c|c|c|}
\hline Date & Area & $N$ & Model & $\begin{array}{l}\text { Integration } \\
\text { depth }(\mathrm{m})\end{array}$ & $\begin{array}{l}C: \text { Th ratio size } \\
\text { fraction }(\mu \mathrm{m})\end{array}$ & Reference/investigator \\
\hline 1987 & Equatorial Pacific & 4 & SS & 80 & Traps & Murray et al. (1989) \\
\hline 1992 & Equatorial Pacific & 24 & SS & 100 & $>53$ & Murray et al. (1996) \\
\hline 1992 & Southern Ocean & 1 & SS & 100 & Part. & Shimmield and Ritchie (1995) \\
\hline 1992 & Equatorial Pacific & 2 & SS & 120 & $>53$ & Bacon et al. (1996) \\
\hline 1993-1994 & Middle Atlantic Bight & 7 & SS & 200 & Traps & Santschi et al. (1999) \\
\hline 1995 & Arabian Sea & 56 & NSS & 100 & $>53$ & Buesseler et al. (1998) \\
\hline 1996 & Equatorial Atlantic & 12 & NSS & 100 & $>53$ & Charette and Moran (1999) \\
\hline 1996 & Subartic Pacific & 3 & SS & $110-210$ & $>53$ & Charette et al. (1999) \\
\hline 1996 & Southern Ocean & 6 & NSS & 100 & Part. & Friedrich and van der Loeff (2002) \\
\hline 1997-1998 & Southern Ocean & 28 & NSS & 100 & $>70$ & Buesseler et al. (2003) \\
\hline 1998-1999 & Arctic & 15 & SS & 100 & $>70$ & Amiel et al. (2002) \\
\hline 1999 & North Pacific & 4 & SS & 100 & Part. & Chen et al. (2003) \\
\hline 1999 & Southern Ocean & 8 & SS & 100 & $>60$ & Coppola et al. (2005) \\
\hline 1999 & Labrador Sea & 3 & SS & 100 & $>53$ & Moran et al. (2003) \\
\hline 2003 & North Pacific & 22 & SS & 100 & Part. & Kawakami et al. (2007) \\
\hline $2003-2005$ & Arctic & 8 & SS & $60-120$ & $>53$ & Lalande et al. (2008) \\
\hline 2003 & Antarctic & 6 & NSS/SS & 100 & $>70$ & Rodriguez y Baena et al. (2008) \\
\hline 2004 & Arctic & 8 & SS & 100 & $>53$ & Lalande et al. (2007) \\
\hline 2004 & Atlantic gyres & 10 & SS & Equ. depth & $>53$ & Thomalla et al. (2008) \\
\hline 2004 & China Sea & 36 & SS & 100 & $>1$ & Cai et al. (2008) \\
\hline 2008 & Southern Ocean & 27 & SS & 100 & $>50$ & Rutgers van der Loeff et al. (2011) \\
\hline 2008 & South-west Pacific & 25 & SS & 100 & Part. & Zhou et al. (2012) \\
\hline 2008 & Southern Ocean & 11 & SS & 100 & $>53$ & Planchon et al. (2013) \\
\hline 2009 & PAP site & 10 & SS & 150 & $>53$ & Le Moigne et al. (2013) \\
\hline 2010 & North Atlantic & 20 & SS & 150 & $>53$ & Le Moigne et al. (2012) \\
\hline
\end{tabular}

fractions for the $\mathrm{POC} /{ }^{234} \mathrm{Th}$ ratios used in the database are given in Table 1.

There is a considerable body of literature on how and why $\mathrm{POC} /{ }^{234} \mathrm{Th}$ ratios vary with particle size and depth (see review in Buesseler et al., 2006); however, there is little consensus on the most appropriate ratio to use. Numerous processes can impact $\mathrm{POC} /{ }^{234} \mathrm{Th}$ ratios in the ocean including particle surface-area-to-volume ratios (Santschi et al., 2006), solution chemistry issues (Guo et al., 2002; Hung et al.,
2004), the chemical composition of particles and their affinity for ${ }^{234}$ Th (Szlosek et al., 2009), POC assimilation by food webs (Buesseler and Boyd, 2009), particle aggregation (Burd et al., 2000) and fragmentation (Maiti et al., 2010) and Th decay (Cai et al., 2006). 


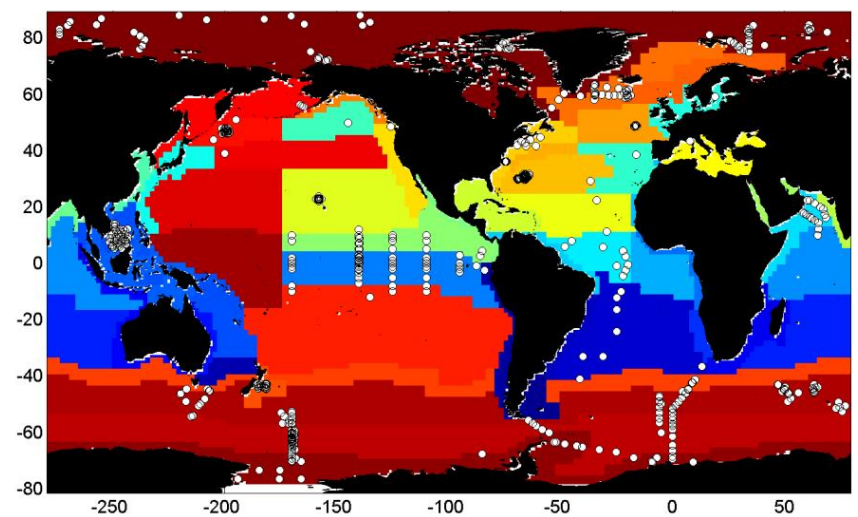

Figure 2. Map showing the distribution of sampling stations. Longhurst oceanic (Longhurst, 2006) provinces are represented in different colours.

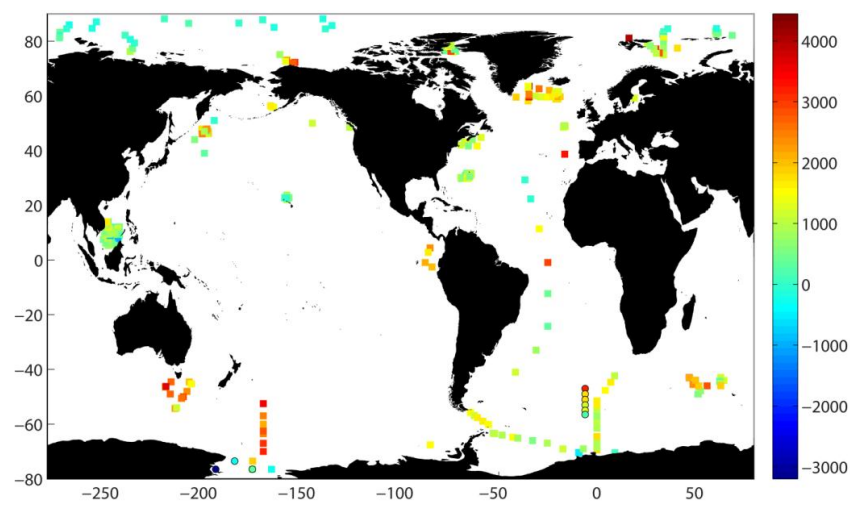

Figure 3. Global distribution of ${ }^{234} \mathrm{Th}$ export fluxes (in dpm $\mathrm{m}^{-2} \mathrm{~d}^{-1}$ ). SS model (see text) derived fluxes are squares and NSS model derived fluxes are circles.

\section{Results and discussion}

\subsection{Data sources}

The dataset is archived on the data repository PANGEA ${ }^{\circledR}$ (www.pangea.de) under doi:10.1594/PANGAEA.809717. Latitude, longitude, date, POC flux, primary production (when available), integration depth and references are given as metadata. All fluxes were converted to $\mathrm{mgC} \mathrm{m}^{-2} \mathrm{~d}^{-1}$ if not already reported in these units. Th-derived POC export has been reported at 723 stations globally (Fig. 2). Some stations were part of transect cruises whereas others were part of small-scale surveys or reoccupation at different seasons and years. Sampling date, sampling area and reference investigator are given in Table 1 in addition to the literature reference. The ${ }^{234} \mathrm{Th}$ fluxes derived from both SS and NSS model are presented in Fig. 3. Because of the uncertainties associated with $\mathrm{POC} /{ }^{234} \mathrm{Th}$ ratios, examining the Th fluxes prior to conversion to POC fluxes provides a robust picture of the variability in particle flux on the global scale. The lowest and highest ${ }^{234} \mathrm{Th}$ flux are both measured in the Arctic Ocean.

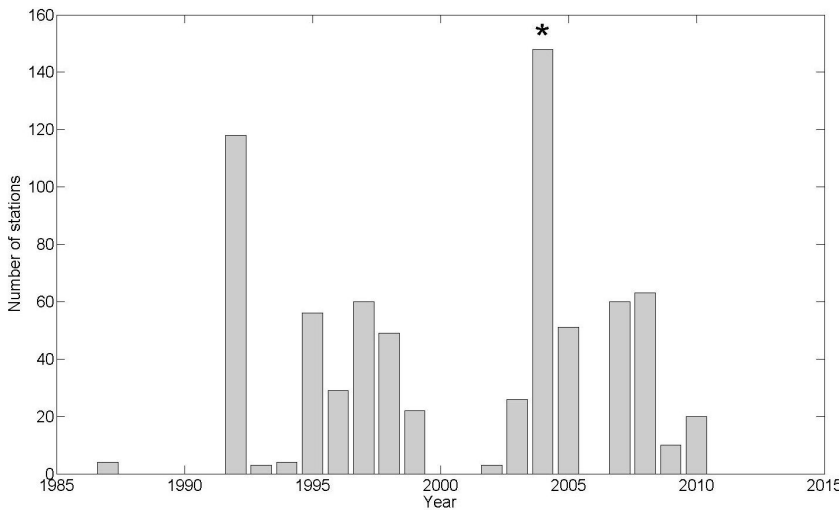

Figure 4. Histogram of datapoints presented in Table 1 and published since 1987. The star indicates the year 2004 when the VERTIGO study was undertaken.

Also, it is worth mentioning that on small scales the ${ }^{234} \mathrm{Th}$ flux can be quite variable, e.g. in the Iceland and Irminger basins (Fig. 3). Generally, the patchiness of export, which can affect the robustness of point observations, is greater in region of high eddy kinetic energy (Resplandy et al., 2012).

Our database covers measurements published between 1985 and 2013. We do not include unpublished data here and therefore assume that the originating authors and editors have undertaken steps necessary to control data quality. Fig. 4 shows the number of thorium-derived export data per year published from 1985 to 2013. In years 1992, 1998 and 2002, the number of ${ }^{234} \mathrm{Th}$ measurements increased. This is likely due to significant improvements in the ${ }^{234} \mathrm{Th}$ methodology such as the introduction of the small volume technique (Benitez-Nelson et al., 2001b), and it also highlights dedicated carbon export programmes such as the VERTIGO voyages in the Pacific Ocean (Buesseler et al., 2008b, 2009). It is important to mention that our database only references papers where Th-derived export data are presented in tables, rather than only graphically.

More POC fluxes are reported in the Northern Hemisphere ( $\sim 60 \%$ of the database) than in the Southern Hemisphere (Fig. 5). In the Northern Hemisphere, each month of the year has been sampled (Fig. 5). Springtime (May) and summertime have been most frequently sampled. In the Southern Hemisphere, although stations are more evenly distributed in time, no ${ }^{234} \mathrm{Th}$-derived POC export numbers are reported for winter months (July and August, Fig. 5).

\subsection{Global POC export and ocean provinces}

${ }^{234}$ Th-derived POC export estimates are reported in 32 out of 56 Longhurst provinces (Longhurst, 2006) that are based on the prevailing role of physical forcing as a regulator of phytoplankton distribution, with measurements in most of the large open ocean biomes (Fig. 2). Figure 6 shows the mean ${ }^{234} \mathrm{Th}$-derived POC export $\left(\mathrm{mg} \mathrm{m}^{-2} \mathrm{~d}^{-1}\right)$ in each 


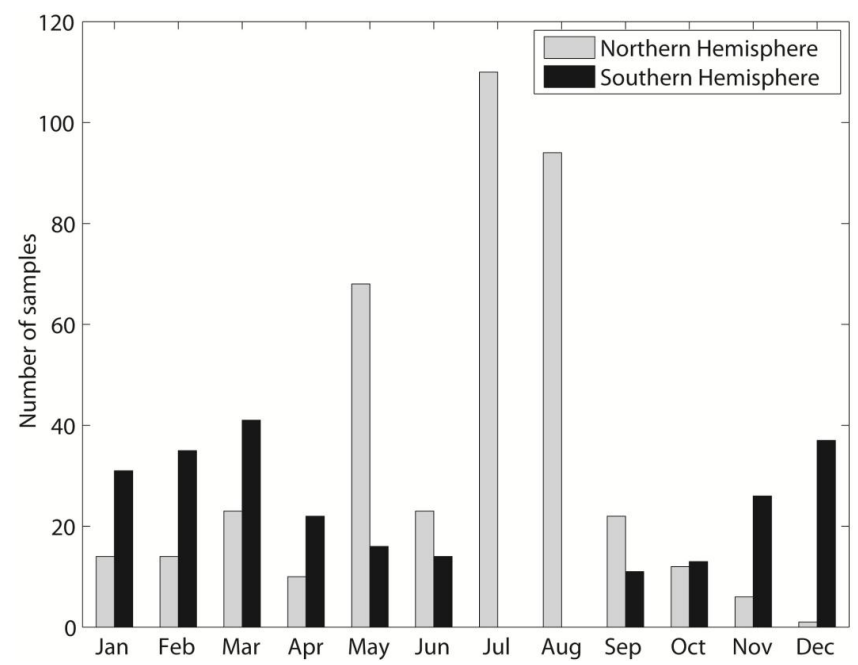

Figure 5. Number of samples collected in each month, separated into Northern Hemisphere and Southern Hemisphere.

Longhurst province that has been sampled at least once. Only four provinces are represented with one measurement (NASE, CCAL, CHIL and NECS; see Table 2 for details and provinces names).

Our dataset exhibits similar global patterns of POC export as those estimated with other methods (e.g. Laws et al., 2000; Schlitzer, 2004), with highest daily POC export rate occurring in the high-latitude North Atlantic, the Arctic and the Southern Ocean. NASE and WTRA provinces located in the subtropical and equatorial Atlantic (Fig. 6 and Table 2) are exceptions to this trend with POC export of 450 (but note that $n=1$ ) and $250 \pm 200 \mathrm{mg} \mathrm{m}^{-2} \mathrm{~d}^{-1}$ reported in Thomalla et al. (2008) and Charette and Moran (1999), respectively. Some regions are relatively well sampled, such as the Arctic Ocean (Longhurst's BPLR), which is represented by 72 stations which display high spatial variability. For instance, POC flux associated with Arctic shelf regions is large while the POC flux in the central Arctic is very low (Cai et al., 2010). This implies that the magnitude of export is not necessarily a simple function of temperature in high-latitude regions.

Some regions show unexpectedly high POC flux, such as the NASE, where Thomalla et al. (2008) suggest that the occurrence of a short-lived bloom triggered by nutrient injection into the surface from a local upwelling event resulted in very high POC flux (however, note that $n=1$ in this region). Alternatively, Charette and Moran (1999) propose that scavenging of ${ }^{234} \mathrm{Th}$ by inorganic particles may have overestimated the POC flux in the WTRA region, as also observed by Le Moigne et al. (2013); Brew et al. (2009).

A comparison of Th-derived export with direct measurements of surface export (from free drifting sediment traps to avoid any problem due to overcollection of horizontally advected material) would be useful at this stage. However, surface POC fluxes from direct measurements are scarce. The few studies that have examined the discrepancy between ${ }^{234} \mathrm{Th}$-derived estimates and direct measurements of POC export (e.g. Le Moigne et al., 2013; Stewart et al., 2007) suggest that ${ }^{234} \mathrm{Th}$-derived estimates in most cases overestimate the direct POC flux. This may be due to a mismatch in timescales over which different methods estimate export. ${ }^{234} \mathrm{Th}$ deficits persist after an export event, whereas free-drifting sediment traps capture only the instantaneous export flux.

\subsection{Towards better understanding of the ocean's biological carbon pump}

A portion of this database has already been used to extrapolate the local measurements to a global scale by correlation with satellite sea surface temperature fields (Henson et al., 2011). The resulting estimates of global integrated carbon export were significantly lower than those derived from new production measurements, at just $\sim 5 \mathrm{GtC} \mathrm{yr}^{-1}$ compared to $12 \mathrm{GtC} \mathrm{yr}^{-1}$ (Laws et al., 2000). However, the parameterisation of the export ratio presented in Henson et al. (2011) has relatively large uncertainty at cold sea surface temperature (SST) (see their Fig. 2). As the type of phytoplankton present in the upper ocean may also influence the export ratio (because large, dense phytoplankton cells sink rapidly and export more efficiently than smaller plankton), the variability in export ratio at low temperatures could be due to large seasonal shifts in phytoplankton community structure at high latitudes.

In high-latitude regions, simultaneous measurements of upper ocean particulate organic carbon flux and phytoplankton community structure could help to assess how seasonal variability of the phytoplankton bloom alters the export ratio. The knowledge gained from this approach could then be applied to our global dataset, combining satellite-derived data on SST, bloom stage and phytoplankton community structure. Ultimately, a revised parameterisation of the export ratio, including relevant seasonal information, could be used to calculate a new global estimate of the magnitude of the biological carbon pump.

\subsection{Significant gaps in the global dataset}

Globally the Th-derived POC fluxes ranged from 0 to $1500 \mathrm{mg}$ of $\mathrm{C} \mathrm{m}^{-2} \mathrm{~d}^{-1}$ (Fig. 7). In this database, some areas such as the equatorial Pacific, Arabian Sea, South China Sea and the high-latitude North Atlantic are fairly well represented (Fig. 7). However, there are significant gaps that could potentially bias estimates of the global carbon export. Most notably, ${ }^{234} \mathrm{Th}$-derived POC fluxes are not reported for the Benguela system (BENG), the Mauritanian upwelling (CNRY; ETRA), the entire western Pacific (consisting of numerous Longhurst provinces), and the southern Indian Ocean (ISSG). 
Table 2. Mean POC flux (mg m $\mathrm{m}^{-2} \mathrm{~d}^{-1}$ ) per Longhurst province (Longhurst, 2006).

\begin{tabular}{|c|c|c|c|c|}
\hline $\begin{array}{l}\text { Province } \\
\text { number }\end{array}$ & Province name & $\begin{array}{r}\text { Mean POC flux } \\
\left(\mathrm{mgC} \mathrm{m}^{-2} \mathrm{~d}^{-1}\right)\end{array}$ & $\begin{array}{r}\text { Standard deviation } \\
\text { in POC flux }\end{array}$ & $\begin{array}{r}\text { Number of } \\
\text { stations }\end{array}$ \\
\hline 2 & CHIL - Chile-Peru Current Coastal & 176.00 & 0 & 1 \\
\hline 5 & SATL - South Atlantic Gyre & 37.44 & 54.38 & 7 \\
\hline 14 & PEQD - Pacific Equatorial Divergence & 46.20 & 40.43 & 71 \\
\hline 15 & MONS - Indian Monsoon Gyre & 62.16 & 54.26 & 10 \\
\hline 19 & ARAB - NW Arabian Upwelling & 85.18 & 82.45 & 48 \\
\hline 20 & WTRA - Western Tropical Atlantic & 251.39 & 178.19 & 10 \\
\hline 22 & NECS - NE Atlantic Shelves & 53.52 & 0 & 1 \\
\hline 23 & NASE - North Atlantic Subtropical Gyre (East) & 488.40 & 0 & 1 \\
\hline 24 & PSAE - Pacific Subarctic Gyre (East) & 49.00 & 32.39 & 6 \\
\hline 26 & INDE - East India Coastal & 31.60 & 15.66 & 3 \\
\hline 28 & PNEC - North Pacific Equatorial Countercurrent & 48.65 & 50.29 & 24 \\
\hline 30 & INDW - West India Coastal & 33.60 & 52.43 & 18 \\
\hline 32 & NPTG - North Pacific Tropical Gyre & 26.27 & 23.57 & 21 \\
\hline 33 & NATR - North Atlantic Tropical Gyre & 91.20 & 128.98 & 2 \\
\hline 34 & MEDI - Mediterranean Sea, Black Sea & 115.80 & 78.70 & 4 \\
\hline 35 & CCAL - California Upwellinf Coastal & 14.76 & 0 & 1 \\
\hline 36 & NWCS - NW Atlantic Shelves & 127.08 & 97.75 & 14 \\
\hline 37 & NASW - North Atlantic Subtropical Gyre (West) & 25.90 & 19.41 & 65 \\
\hline 39 & NADR - North Atlantic Drift & 87.56 & 51.22 & 11 \\
\hline 41 & ARCT - Atlantic Arctic & 242.34 & 122.65 & 16 \\
\hline 42 & SARC - Atlantic Subarctic & 214.67 & 127.06 & 14 \\
\hline 44 & SSTC - South Subtropical Convergence & 114.34 & 136.16 & 7 \\
\hline 45 & SPSG - South Pacific Subtropical Gyre & 28.79 & 13.73 & 10 \\
\hline 47 & BERS - North Pacific Epicontinental & 146.00 & 24.04 & 3 \\
\hline 50 & ANTA - Antarctic & 156.95 & 100.90 & 67 \\
\hline 51 & SANT - Subantarctic & 126.54 & 116.71 & 107 \\
\hline 53 & APLR - Austral Polar & 195.07 & 233.32 & 41 \\
\hline 54 & BPLR - Boreal Polar & 171.05 & 298.48 & 72 \\
\hline
\end{tabular}

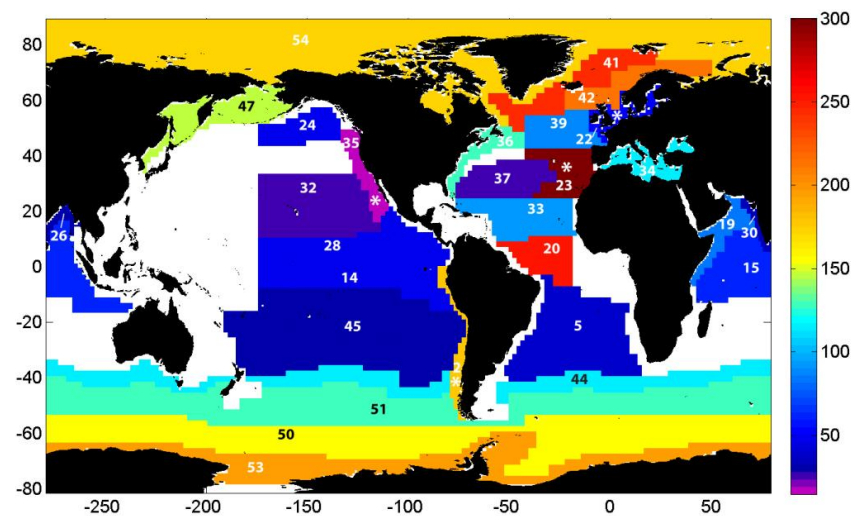

Figure 6. Mean POC export $\left(\mathrm{mg} \mathrm{m}^{-2} \mathrm{~d}^{-1}\right)$ in Longhurst provinces (provinces with only one measurement are marked with a star). Areas in white represent areas where no data have been collected. Numbers on map indicate Longhurst province (cf. Table 2).

Some of these areas are deemed to be high production and export regions due to the occurrence of upwelling. For example, deep $(\sim 2000 \mathrm{~m})$ sediment trap measurements of POC

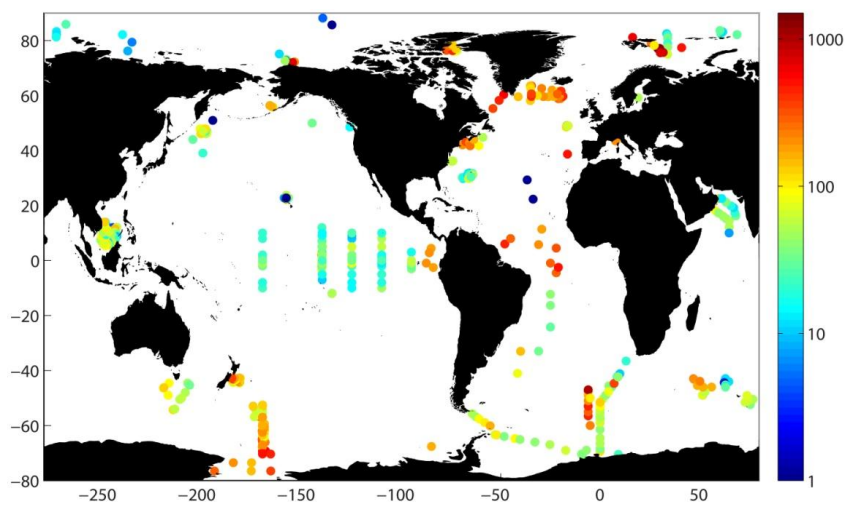

Figure 7. Global distribution of POC export fluxes derived from the ${ }^{234} \mathrm{Th}$ technique (in $\mathrm{mg} \mathrm{m}^{-2} \mathrm{~d}^{-1}$ ).

export for the Mauritanian upwelling suggest that POC flux can peak at 5 to $25 \mathrm{mg} \mathrm{m}^{-2} \mathrm{~d}^{-1}$ (Fischer et al., 2009), and is therefore presumably higher in the upper water column. Also, in the Benguela system POC export has been estimated to be $550 \mathrm{mg} \mathrm{m}^{-2} \mathrm{~d}^{-1}$ on the basis of nutrient uptake (Waldron et al., 1992). Provinces such as KURO and PSAW in 
the north-west Pacific may also export a significant amount of POC $\left(\sim 120 \mathrm{mg} \mathrm{m}^{-2} \mathrm{~d}^{-1}\right.$ averaged over one year based on a modelling study (Schlitzer, 2004). Although these regions represent a small percentage of the global surface area of the ocean, the lack of data in these high export areas could potentially result in estimates of global POC export that are biased low.

We suggest that future studies should investigate ${ }^{234} \mathrm{Th}$ derived POC export flux in regions that are currently unsampled or undersampled. However, in upwelling regions where advective current velocities are high, the influence of advection and diffusion on the ${ }^{234} \mathrm{Th}$ model should be carefully assessed and accounted for in the calculation of POC flux, as done, for example, in Morris et al. (2007), Buesseler et al. (1998), and Charette et al. (1999).

\section{Conclusions}

Here we provide a global database of 723 published estimates of POC export derived from the ${ }^{234} \mathrm{Th}$ technique spanning 1985-2013. The observed pattern of POC fluxes reflects the expected dynamics of primary production and export. Some notable gaps in the dataset are the Benguela system, the Mauritanian upwelling, the western Pacific, and the southern Indian Ocean. This database could be used to provide revised and more robust estimates of the ocean's biological carbon pump.

Acknowledgements. This work was supported by NERC grants NE/G013055/1 and NE/J004383/1 to SAH. Ken Buesseler (WHOI) is acknowledged for sharing data. We thank K. Cochran, M. Rutgers van der Loeff and the editor, Robert Key, for providing useful comments on this paper.

Edited by: R. Key

\section{References}

Amiel, D., Cochran, J. K., and Hirschberg, D. J.: Th-234/U-238 disequilibrium as an indicator of the seasonal export flux of particulate organic carbon in the North Water, Deep-Sea Res. Pt. II, 49, 5191-5209, 2002.

Bacon, M. P., Cochran, J. K., Hirschberg, D., Hammar, T. R., and Fleer, A. P.: Export flux of carbon at the equator during the EqPac time-series cruises estimated from ${ }^{234} \mathrm{Th}$ measurements, DeepSea Res. Pt. II, 43, 1133-1153, 1996.

Benitez-Nelson, C., Buesseler, K. O., Karl, D. M., and Andrews, J.: A time-series study of particulate matter export in the North Pacific Subtropical Gyre based on Th-234 : U-238 disequilibrium, Deep-Sea Res. Pt. I, 48, 2595-2611, 2001a.

Benitez-Nelson, C. R., Buesseler, K. O., van der Loeff, M. R., Andrews, J., Ball, L., Crossin, G., and Charette, M. A.: Testing a new small-volume technique for determining Th-234 in seawater, J. Radioanal. Nucl. Ch., 248, 795-799, 2001 b.

Bishop, J. K. B., Edmond, J. M., Ketten, D. R., Bacon, M. P., and Silker, W. B.: The chemistry, biology, and vertical flux of par- ticulate matter from the upper $400 \mathrm{~m}$ of the equatorial Atlantic Ocean, Deep-Sea Res., 24, 511-548, 1977.

Boyd, P. W. and Newton, P. P.: Does planktonic community structure determine downward particulate organic carbon flux in different oceanic provinces?, Deep-Sea Res. Pt. I, 46, 63-91, 1999.

Brew, H. S., Moran, S. B., Lomas, M. W., and Burd, A. B.: Plankton community composition, organic carbon and thorium-234 particle size distributions, and particle export in the Sargasso Sea, J. Mar. Res., 67, 845-868, 2009.

Buesseler, K., Ball, L., Andrews, J., Benitez-Nelson, C., Belastock, R., Chai, F., and Chao, Y.: Upper ocean export of particulate organic carbon in the Arabian Sea derived from thorium-234, Deep-Sea Res. Pt. II, 45, 2461-2487, 1998.

Buesseler, K. O.: The decoupling of production and particulate export in the surface ocean, Global Biogeochem. Cy., 12, 297-310, 1998.

Buesseler, K. O. and Boyd, P. W.: Shedding light on processes that control particle export and flux attenuation in the twilight zone of the open ocean, Limnol. Oceanogr., 54, 1210-1232, 2009.

Buesseler, K. O., Bacon, M. P., Cochran, J. K., and Livingston, H. D.: Carbon and nitrogen export during the JGOFS North Atlantic Bloom Experiment estimated from ${ }^{234} \mathrm{Th}:{ }^{238} \mathrm{U}$ disequilibria, Deep-Sea Res. Pt. I, 39, 1115-1137, 1992.

Buesseler, K. O., Andrews, J. A., Hartman, M. C., Belastock, R., and Chai, F.: Regional estimates of the export flux of particulate organic carbon derived from thorium-234 during the JGOFS EqPac program, Deep-Sea Res. Pt. II, 42, 777-804, 1995.

Buesseler, K. O., Benitez-Nelson, C. R., Rutgers van der Loeff, M., Andrews, J., Ball, L., Crossin, G., and Charette, M. A.: An intercomparison of small- and large-volume techniques for thorium234 in seawater, Mar. Chem., 74, 15-28, 2001.

Buesseler, K. O., Barber, R. T., Dickson, M. L., Hiscock, M. R., Moore, J. K., and Sambrotto, R.: The effect of marginal ice-edge dynamics on production and export in the Southern Ocean along 170 degrees W, Deep-Sea Rese. Pt. II, 50, 579-603, doi:10.1016/s0967-0645(02)00585-4, 2003.

Buesseler, K. O., Benitez-Nelson, C. R., Moran, S. B., Burd, A., Charette, M., Cochran, J. K., Coppola, L., Fisher, N. S., Fowler, S. W., Gardner, W., Guo, L. D., Gustafsson, O., Lamborg, C., Masque, P., Miquel, J. C., Passow, U., Santschi, P. H., Savoye, N., Stewart, G., and Trull, T.: An assessment of particulate organic carbon to thorium-234 ratios in the ocean and their impact on the application of Th-234 as a POC flux proxy, Mar. Chem., 100, 213-233, doi:10.1016/j.marchem.2005.10.013, 2006.

Buesseler, K. O., Lamborg, C., Cai, P., Escoube, R., Johnson, R., Pike, S., Masque, P., McGillicuddy, D., and Verdeny, E.: Particle fluxes associated with mesoscale eddies in the Sargasso Sea, Deep-Sea Res. Pt. II, 55, 1426-1444, doi:10.1016/j.dsr2.2008.02.007, 2008a.

Buesseler, K. O., Trull, T. W., Steinber, D. K., Silver, M. W., Siegel, D. A., Saitoh, S. I., Lamborg, C. H., Lam, P. J., Karl, D. M., Jiao, N. Z., Honda, M. C., Elskens, M., Dehairs, F., Brown, S. L., Boyd, P. W., Bishop, J. K. B., and Bidigare, R. R.: VERTIGO (VERtical Transport in the Global Ocean): A study of particle sources and flux attenuation in the North Pacific, Deep-Sea Res. Pt. II, 55, 1522-1539, doi:10.1016/j.dsr2.2008.04.024, 2008b.

Buesseler, K. O., Pike, S., Maiti, K., Lamborg, C. H., Siegel, D. A., and Trull, T. W.: Thorium-234 as a tracer of spatial, temporal and vertical variability in particle flux in the North Pacific, Deep-Sea 
Res. Pt. I, 56, 1143-1167, doi:10.1016/j.dsr.2009.04.001, 2009.

Burd, A. B., Moran, S. B., and Jackson, G. A.: A coupled adsorption-aggregation model of the POC/Th-234 ratio of marine particles, Deep-Sea Res. Pt. I, 47, 103-120, 2000.

Cai, P., Dai, M., Chen, W., Tang, T., and Zhou, K.: On the importance of the decay of ${ }^{234} \mathrm{Th}$ in determining size-fractionated $\mathrm{C} /{ }^{234} \mathrm{Th}$ ratio on marine particles, Geophys. Res. Lett., 33, L23602, doi:10.1029/2006GL027792, 2006.

Cai, P., Chen, W., Dai, M., Wan, Z., Wang, D., Li, Q., Tang, T., and Lv, D.: A high-resolution study of particle export in the southern South China Sea based on ${ }^{234} \mathrm{Th}:{ }^{238} \mathrm{U}$ disequilibrium, J. Geophys. Res., 113, CB4019, doi:10.1029/2007JC004268, 2008.

Cai, P., Rutgers van der Loeff, M., Stimac, I., Nothig, E. M., Lepore, K., and Moran, S. B.: Low export flux of particulate organic carbon in the central Artic Ocean as revealed by ${ }^{234} \mathrm{Th}:{ }^{238} \mathrm{U}$ disequilibrium, J. Geophys. Res., 115, C10037, doi:10.1029/2009JC005595, 2010.

Cai, P. H., Huang, Y. P., Chen, M., Liu, G. S., and Qiu, Y. S.: Export of particulate organic carbon estimated from Th-234-U-238 disequilibria and its temporal variation in the South China Sea, Chinese Sci. Bull., 46, 1722-1726, 2001.

Charette, M. A. and Moran, S. B.: Rates of particle scavenging and particulate organic carbon export estimated using ${ }^{234} \mathrm{Th}$ as a tracer in the subtropical and equatorial Atlantic Ocean, DeepSea Res. Pt. II, 46, 885-906, 1999.

Charette, M. A., Moran, S. B., and Bishop, J. K. B.: Th-234 as a tracer of particulate organic carbon export in the subarctic northeast Pacific Ocean, Deep-Sea Res. Pt. II, 46, 2833-2861, 1999.

Charette, M. A., Moran, S. B., Pike, S. M., and Smith, J. N.: Investigating the carbon cycle in the Gulf of Maine using the natural tracer thorium 234, J. Geophys. Res.-Oceans, 106, 11553-11579, 2001.

Chen, J. H., Edwards, R. L., and Wasserburg, G. J.: ${ }^{238} \mathrm{U},{ }^{234} \mathrm{U}$ and ${ }^{232}$ Th in seawater, Earth Planet. Sc. Lett., 80, 241-251, 1986.

Chen, M., Huang, Y. P., Cai, P. G., and Guo, L. D.: Particulate organic carbon export fluxes in the Canada Basin and Bering Sea as derived from Th-234/U-238 disequilibria, Arctic, 56, 32-44, 2003.

Coale, K. H. and Bruland, K. W.: Oceanic stratified euphotic zone as elucidated by ${ }^{234} \mathrm{Th} .{ }^{238} \mathrm{U}$ disequilibria, Limnol. Oceanogr., 32 , 189-200, 1987.

Cochran, J. K. and Masque, P.: Short-lived U/Th series radionuclides in the ocean: Tracers for scavenging rates, export fluxes and particle dynamics, Uranium-Series Geochemistry, 52, 461492, 2003.

Cochran, J. K., Buesseler, K. O., Bacon, M. P., Wang, H. W., Hirschberg, D. J., Ball, L., Andrews, J., Crossin, G., and Fleer, A.: Short-lived thorium isotopes (Th-234, Th-228) as indicators of POC export and particle cycling in the Ross Sea, Southern Ocean, Deep-Sea Res. Pt. II, 47, 3451-3490, 2000.

Coppola, L., Roy-Barman, M., Mulsow, S., Povinec, P., and Jeandel, C.: Low particulate organic carbon export in the frontal zone of the Southern Ocean (Indian sector) revealed by ${ }^{234} \mathrm{Th}$, Deep-Sea Res. Pt. I, 52, 51-68, 2005.

Eppley, R. W. and Peterson, B. J.: Particulate organic matter flux and planktonic new production in the deep ocean, Nature, 282, 677-680, 1979.

Fischer, G., Karakas, G., Blaas, M., Ratmeyer, V., Nowald, N., Schlitzer, R., Helmke, P., Davenport, R., Donner, B., Neuer, S., and Wefer, G.: Mineral ballast and particle settling rates in the coastal upwelling system off NW Africa and the South Atlantic, Int. J. Earth Sci., 98, 281-298, doi:10.1007/s00531-007-0234-7, 2009.

Fowler, S. W. and Knauer, G. A.: Role of large particles in the transport of elements and organic compounds through the oceanic water column, Prog. Oceanogr., 16, 147-194, 1986.

Friedrich, J. and van der Loeff, M. M. R.: A two-tracer (Po-210-Th234) approach to distinguish organic carbon and biogenic silica export flux in the Antarctic Circumpolar Current, Deep-Sea Res. Pt. I, 49, 101-120, 2002.

Guo, L., Hung, C.-C., Santschi, P. H., and Walsh, I. D.: ${ }^{234}$ Th scavenging and its relationship to acid polysaccharide abundance in the Gulf of Mexico, Mar. Chem., 78, 103-119, 2002.

Henson, S., Sanders, R., Madsen, E., Morris, P., Le Moigne, F., and Quartly, G.: A reduced estimate of the strength of the ocean's bioloical carbon pump, Geophys. Res. Lett., 38, L04606, doi:10.1029/2011GL046735, 2011.

Henson, S. A., Sanders, R., Holeton, C., and Allen, J. T.: Timing of nutrient depletion, diatom dominance and a lower-boundary estimate of export production for Irminger Basin, North Atlantic, Mar. Ecol.-Prog. Ser., 313, 73-84, 2006.

Honjo, S., Manganini, S. J., Krishfield, R. A., and Francois, R.: Particulate organic carbon fluxes to the ocean interior and factors controlling the biological pump: A synthesis of global sediment trap programs since 1983, Prog. Oceanogr., 76, 217-285, doi:10.1016/j.pocean.2007.11.003, 2008.

Hung, C. C., Guo, L. D., Roberts, K. A., and Santschi, P. H.: Upper ocean carbon flux determined by size-fractionated 234Th data and sediment traps in the Gulf of Mexico, Geochem. J., 38, 601611, 2004.

Jacquet, S. H. M., Lam, P. J., Trull, T., and Dehairs, F.: Carbon export production in the subantarctic zone and polar front zone South of Tasmania, Deep-Sea Res. Pt. II, 58, 2277-2292, 2011.

Jenkins, W. J.: Oxygen Utilization Rates in North-Atlantic SubTropical Gyre and Primary Production in Oligotrophic Systems, Nature, 300, 246-248, 1982.

Kawakami, H., Honda, M. C., Wakita, M., and Watanabe, S.: Timeseries observation of POC fluxes estimated from ${ }^{234} \mathrm{Th}$ in the northwestern North Pacific, Deep-Sea Res. Pt. I, 54, 1070-1090, 2007.

Ku, T. L., Knauss, K. G., and Mathieu, G. G.: Uranium in open ocean: concentration and isotopic composition, Deep-Sea Res., 24, 1005-1017, 1977.

Lalande, C., Lepore, K., Cooper, L. W., Grebmeier, J. M., and Moran, S. B.: Export fluxes of particulate organic carbon in the Chukchi Sea: A comparative study using ${ }^{234} \mathrm{Th} /{ }^{238} \mathrm{U}$ disequilibria and drifting sediment traps, Mar. Chem., 103, 185-196, 2007.

Lalande, C., Moran, S. B., Wassmann, P., Grebmeier, J. M., and Cooper, L. W.: ${ }^{234}$ Th-derived particulate organic carbon fluxes in the northern Barents Sea with comparison to drifting sediment trap fluxes, J. Mar. Syst., 73, 103-113, 2008.

Lampitt, R. S., Boorman, B., Brown, L., Lucas, M., Salter, I., Sanders, R., Saw, K., Seeyave, S., Thomalla, S. J., and Turnewitsch, R.: Particle export from the euphotic zone: Estimates using a novel drifting sediment trap, Th-234 and new production, Deep-Sea Res. Pt. I, 55, 1484-1502, doi:10.1016/j.dsr.2008.07.002, 2008. 
Laws, E. A., Falkowski, P. G., Smith, W. O., Ducklow, H., and McCarthy, J. J.: Temperature effects on export production in the open ocean, Global Biogeochem. Cy., 14, 1231-1246, 2000.

Le Moigne, F. A. C., Sanders, R. J., Villa-Alfageme, M., Martin, A. P., Pabortsava, K., Planquette, H., Morris, P. J., and Thomalla, S. J.: On the proportion of ballast versus non-ballast associated carbon export in the surface ocean, Geophys. Res. Lett., 39, L15610, doi:10.1029/2012GL052980, 2012.

Le Moigne, F. A. C., Villa-Alfageme, M., Sanders, R. J., Marsay, C. M., Henson, S., and Garcia-Tenorio, R.: Export of organic carbon and biominerals derived from ${ }^{234} \mathrm{Th}$ and ${ }^{210} \mathrm{Po}$ at the Porcupine Abyssal Plain, Deep-Sea Res. Pt. I, 72, 88-101, doi:10.1016/j.dsr.2012.10.010, 2013.

Longhurst, A. R.: Ecological Geography of the Sea (Second Edition), Elsevier Inc., ISBN: 978-0-12-455521-1, 2006.

Maiti, K., Benitez-Nelson, C. R., and Buesseler, K.: Insights into particle formation and remineralization using the short-lived radionuclide, Thorium-234, Geophys. Res. Lett., 37, L15608, doi:10.1029/2010GL044063, 2010.

Moran, S. B., Weinstein, S. E., Edmonds, H. N., Smith, J. N., Kelly, R. P., Pilson, M. E. Q., and Harrison, W. G.: Does ${ }^{234} \mathrm{Th} /{ }^{238} \mathrm{U}$ disequilibrium provide an acurate record of the export flux of particulate organic carbon from the upper ocean?, Limnol. Oceanogr., 48, 1018-1029, 2003.

Morris, P. J., Sanders, R., Turnewitsch, R., and Thomalla, S.: Th234-derived particulate organic carbon export from an islandinduced phytoplankton bloom in the Southern Ocean, DeepSea Res. Pt. II, 54, 2208-2232, doi:10.1016/j.dsr2.2007.06.002, 2007.

Murray, J. W., Downs, J. N., Strom, S., Wei, C. L., and Jannasch, H. W.: Nutrient assimilation, export production and ${ }^{234} \mathrm{Th}$ scavenging in the eastern equatorial Pacific, Deep-Sea Res., 36, 1471$1489,1989$.

Murray, J. W., Leinen, M. W., Feely, R. A., Toggweiler, J. R., and Wanninkhof, R.: EqPac: A process study in the Central Equatorial Pacific, Oceanography, 5, 134-142, 1992.

Murray, J. W., Young, J., Dunne, J. P., Chapin, T., and Paul, B.: Export flux of particulate organic carbon frm the Central Equatorial Pacific determined using a combined drifting trap- ${ }^{234}$ Th approach, Deep-Sea Res. Pt. II, 43, 1095-1132, 1996.

Planchon, F., Cavagna, A.-J., Cardinal, D., André, L., and Dehairs, F.: Late summer particulate organic carbon export and twilight zone remineralisation in the Atlantic sector of the Southern Ocean, Biogeosciences, 10, 803-820, doi:10.5194/bg-10-8032013, 2013.

Pondaven, P., Ragueneau, O., Treguer, P., Hauvespre, A., Dezileau, L., and Reyss, J. L.: Resolving the 'opal paradox' in the Southern Ocean, Nature, 405, 168-172, 2000.

Resplandy, L., Martin, A. P., Le Moigne, F., Martin, P., Aquilina, A., Memery, L., Levy, M., and Sanders, R.: How does dynamical spatial variabilty impact ${ }^{234} \mathrm{Th}$-derived estimates of organic export?, Deep-Sea Res. Pt. I, 68, 24-45, 2012.

Rodriguez y Baena, A. M., Boudjenoun, R., Fowler, S. W., Miquel, J. C., Masque, P., Sanchez-Cabeza, J. A., and Warnau, M.: ${ }^{234}$ Thbased carbon export during the ice-edge bloom: Sea-ice algae as a likely bias in data interpretation, Earth Planet. Sc. Lett., 269, 596-604, 2008.

Rutgers van der Loeff, M., Friedrich, J., and Bathmann, U.: Carbon export during the spring bloom at the Antarctic Polar Front, de- termined with the natural tracer ${ }^{234} \mathrm{Th}$, Deep-Sea Res. Pt. II, 44 , 457-478, 1997a.

Rutgers Van Der Loeff, M. M., Bathmann, U. V., and Buesseler, K. O.: Export production measured with the natural tracer Th-234 and sediment traps, Berichte zur Polarforschung, 0, 113-115, $1997 b$.

Rutgers van der Loeff, M., Cai, P., Stimac, I., Bracher, A., Middag, R., Klunder, M., and van Heuven, S.: ${ }^{234}$ Th in surface waters: distribution of particle export flux across the Antarctic Circumpolar Current and in the Weddell Sea during the GEOTRACES expedition ZERO and DRAKE, Deep-Sea Res. Pt. II, 58, 2749-2766, 2011.

Sanders, R., Brown, L., Henson, S., and Lucas, M.: New production in the Irminger Basin during 2002, J. Marine Syst., 55, 291-310, doi:10.1016/j.jmarsys.2004.09.002, 2005.

Sanders, R., Morris, P. J., Poulton, A. J., Stinchcombe, M. C., Charalampopoulou, A., Lucas, M. I., and Thomalla, S. J.: Does a ballast effect occur in the surface ocean?, Geophys. Res. Lett., 37, L08602, doi:10.1029/2010g1042574, 2010.

Santschi, P. H., Guo, L., Walsh, I. D., Quigley, M. S., and Baskaran, M.: Boundary exchange and scavenging of radionuclides in continental margin waters of the middle Atlantic Bight. Implications for carbon fluxes, Cont. Shelf Res., 19, 609-636, 1999.

Santschi, P. H., Murray, J. W., Baskaran, M., Benitez-Nelson, C. R., Guo, L. D., Hung, C. C., Lamborg, C., Moran, S. B., Passow, U., and Roy-Barman, M.: Thorium speciation in seawater, Mar. Chem., 100, 250-268, 2006.

Sarmiento, J. L. and Toggweiler, J. R.: A new model for the role of the oceans in determining atmospheric $\mathrm{pCO}_{2}$, Nature, 308, 621624, 1984.

Savoye, N., Benitez-Nelson, C., Burd, A. B., Cochran, J. K., Charette, M., Buesseler, K. O., Jackson, G. A., Roy-Barman, M., Schmidt, S., and Elskens, M.: Th-234 sorption and export models in the water column: A review, Mar. Chem., 100, 234-249, doi:10.1016/j.marchem.2005.10.014, 2006.

Savoye, N., Trull, T. W., Jacquet, S. H. M., Navez, J., and Dehairs, F.: ${ }^{234}$ Th-based export fluxes during a natural iron fertilization experiemnt in the Southern Ocean (KEOPS), Deep-Sea Res. Pt. II, 55, 841-855, 2008.

Schlitzer, R.: Export production in the equatorial and North Pacific derived from dissolved oxygen, nutrient and carbon data, J. Oceanogr., 60, 53-62, 2004.

Shimmield, G. B. and Ritchie, G. R.: The impact of marginal ice zone processes on the distribution of ${ }^{210} \mathrm{~Pb},{ }^{210} \mathrm{Po}$ and ${ }^{234} \mathrm{Th}$ and implications for new production in the Bellingshausen Sea, Antarctica, Deep-Sea Res. Pt. II, 42, 1313-1335, 1995.

Stewart, G., Cochran, J. K., Miquel, J. C., Masque, P., Szlosek, J., Baena, A., Fowler, S. W., Gasser, B., and Hirschberg, D. J.: Comparing POC export from Th-234/U-238 and Po-210/Pb210 disequilibria with estimates from sediment traps in the northwest Mediterranean, Deep-Sea Res. Pt. I, 54, 1549-1570, doi:10.1016/j.dsr.2007.06.005, 2007.

Szlosek, J., Cochran, J. K., Miquel, J. C., Masque, P., Armstrong, R. A., Fowler, S. W., Gasser, B., and Hirschberg, D. J.: Particulate organic carbon-Th relationships in particles separated by settling velocity in the northwest Mediterranean Sea, Deep-Sea Res. Pt. II, 56, 1519-1532, 2009.

Thomalla, S. J., Poulton, A. J., Sanders, R., Turnewitsch, R., Holligan, P. M., and Lucas, M. I.: Variable export fluxes and 
efficiencies for calcite, opal, and organic carbon in the Atlantic Ocean: A ballast effect in action?, Global Biogeochem. Cy., 22, Gb1010, doi:10.1029/2007gb002982, 2008.

Van der Loeff, M. R., Sarin, M. M., Baskaran, M., Benitez-Nelson, C., Buesseler, K. O., Charette, M., Dai, M., Gustafsson, O., Masque, P., Morris, P. J., Orlandini, K., Baena, A. R. Y., Savoye, N., Schmidt, S., Turnewitsch, R., Voge, I., and Waples, J. T.: A review of present techniques and methodological advances in analyzing Th-234 in aquatic systems, Mar. Chem., 100, 190-212, doi:10.1016/j.marchem.2005.10.012, 2006.

Verdeny, E., Masque, P., Maiti, K., Garcia-Orellana, J., Brauch, J. M., Mahaffey, C., and Benitez-Nelson, C. R.: Particle export within cyclonic Hawaiian lee eddies derived from $\mathrm{Pb}-210-$ Po-210 disequilibrium, Deep-Sea Res. Pt. II, 55, 1461-1472, doi:10.1016/j.dsr2.2008.02.009, 2008.
Waldron, H. N., Probyn, T. A., Lutjeharms, J. R. E., and Shillington, F. A.: Carbon export associated with the Benguela upwelling system, S. Afr. J. Marine Sci., 12, 369-374, 1992.

Waples, J. T., Benitez-Nelson, C., Savoye, N., Van der Loeff, M. R., Baskaran, M., and Gustafsson, O.: An introduction to the application and future use of Th-234 in aquatic systems, Mar. Chem., 100, 166-189, doi:10.1016/j.marchem.2005.10.011, 2006.

Zhou, K., Nodder, S. D., Dai, M., and Hall, J. A.: Insignificant enhancement of export flux in the highly productive subtropical front, east of New Zealand: a high resolution study of particle export fluxes based on ${ }^{234} \mathrm{Th}:{ }^{238} \mathrm{U}$ disequilibria, Biogeosciences, 9, 973-992, doi:10.5194/bg-9-973-2012, 2012. 